\title{
Discriminant Analysis of Morphological Traits in Selected Population of the Tiv Local Chicken Ecotype in the Derived Guinea Savanah of Nigeria
}

\author{
${ }^{1}$ Deeve S. Gwaza, ${ }^{1}$ Noah .E.T. Tor, and ${ }^{2}$ Thomas I.Wamagi. \\ ${ }^{I}$ Department of Animal Breeding and Physiology, University of Agriculture, Makurdi, Nigeria. \\ ${ }^{2}$ Department of Animal Science, Kaduna State University, Nigeria.
}

\begin{abstract}
The study was conducted at four villages of Katsina- Ala Local Government Area of Benue State of Nigeria. Measurements were taken on 1378 birds on body linear parameters and weight. The data generated were subjected to discriminant analysis to estimate group statistics, test of equality of group means, canonical correlation coefficients, Wilks' lambda, structure matrix and classification statistics. The high value of canonical correlation coefficients indicated the strength of the models that explained the variation existing between the groups. The significance of the discriminant functions indicated their strength that differentiated between the groups. There were variations in body dimensions between isolated populations of the Tiv Local chicken ecotype. These morphological measurements can be used to increase consistency of individuals in a population and separation of individuals between populations.
\end{abstract}

Key words: Canonical correlation, Classification statistics and Discriminant function.

\section{Introduction}

Local chickens constitute 89 percent of the 120 million poultry found in Nigeria (Fayeye et al., 2006). The local chicken resource is economically important to the people of Nigeria and the developing world at large. This is because the rearing of local chickens demands use of very little resources and financial rewards are in a short term. The local chicken resource is an important tool for poverty alleviation in Nigeria. Adaptation of the local chicken ecotypes in tropical environment has been through reduction in body size as a means of reducing maintenance feed requirement and increasing feed efficiency (Rashid et al., 2005). The Nigerian local chicken possesses small body size and grows slowly (Nwosu et al., 1985). Growth rate and egg production under traditional system of rearing in the villages are very low (Ibe, 1998). Fertility and hatchability ranges from 52.487.0 percent (Islam and Nishibor, 2009).

Attempts to provide adequate diet to improve performance economically has not been justifiable (Pedersen, 2002; Lwesya et al., 2004) Genetic improvement of the local chicken for effective utilization of dietary nutrients appeared the most economically option for improving performance in the sector (Olawunmi et al., 2008). In Nigeria, local chicken were characterized along genetic line of feather and plumage colour (Adedokun and Sonaiya, 2001). Classification has also been on the basis of location (Momoh et al., 2007) which does not take into account genetic variation of chickens within the different agro-ecological zones of Nigeria (Olori 1992; Nwosu 1990; Oluyemi et al., 1982 and Gwaza et al., 2013). The origin of each ecotype is the product of mutation, genetic drift, separate adaptation, differing selection pressure imposed by climate, man and available nutrition (Barker, 1994). Thus each ecotype comprises of a number of diversified adaptive and productive traits, and genes even within isolated populations with special utility in their locations (Daguma, 2006). The Tiv local chicken ecotype found in the derived southern guinea savannah zone of Nigeria occurred in huge numbers that are raised predominantly by the traditional family-based free range system (Alemu and Tadelle, 1997). This ecotypes is expected to poses diversified adaptive and productive trait that, if identified, will form the basis for selection and breeding strategies for genetic improvement in the rural poultry production. This study was based on the hypothesis that the Nigerian local Chicken ecotypes within the savannah region are homogenous with no genetic distance between them. It is in view of the above that this study was designed to investigate the variation in body measurements between isolated populations of the Tiv ecotype with the aim to highlight the existence of different body sizes within the ecotype that can be selected for genetic improvement.

\section{Materials and Methods}

The study was conducted at four villages (Kpumtyo, Weryina, Kewanger and Udende ) of Katsina Ala Local Government area of Benue State, Nigeria.

Location. Katsina-Ala is located on latitude $7^{\circ} 11^{\prime \prime}$ and longitude $9^{\circ} 20^{\prime \prime}$. (climate? Vegetation?) The selected villages were rural farming communities that practiced livestock-crop integrated farming. 
Flock Management. The local chickens were the predominant poultry species owned by members of the selected communities, and reared under free range management system - scavenging for kitchen waste, farm by by-products, insects, worms etc. Water and cereal grains were offered occasionally as feed supplement. Medication was never provided. Incubation, hatching and blooding were all through natural processes.

Housing. Poorly constructed housing of local materials were provided for the birds by some of the farmers.

Data Analysis. Measurements were taken on 1378 adult birds for body length, body height, shank length, thigh length, tail length, tail width, comb length, comb height, wattle length, wattle height, and body weight. The data generated were subjected to discriminant analysis of spss 2004; to estimate group statistics, test of equality of group means, canonical discriminant functions, canonical correlation coefficients, Wilks lambda, structure matrix and classification statistic. The following discriminant function models were extracted.

$\begin{aligned} & \mathrm{D} 1=(-0.466 \times \mathrm{BoL})+(0.441 \times \mathrm{BoH})+(-1.189 \times \mathrm{ShL})+(0.029 \times \mathrm{ThL})+(-0.273 \times \mathrm{TaL})+(0.511 \times \mathrm{TaW})+ \\ &(0.032 \times \mathrm{ComH})+(0.046 \times \mathrm{ComL})+(0.201 \times \mathrm{WaL})+(0.364 \times \mathrm{WaH})+(0.073 \times \mathrm{BoW})+(-95.515) . \\ & \mathrm{D} 2=(-0.393 \times \mathrm{BoL})+(0.719 \times \mathrm{BoH})+(-0.142 \times \mathrm{ShL})+(-0.764 \times \mathrm{ThL})+(0.812 \times \mathrm{TaL})+(0.039 \times \mathrm{TaW})+ \\ &(-0.380 \times \mathrm{ComL})+(-0.473 \times \mathrm{ComH})+(0.017 \times \mathrm{WaL})+(0.443 \times \mathrm{WaH})+(0.19 \times \mathrm{BoW})-(-95.905) \\ & \mathrm{D} 3=(0.664 \times \mathrm{BoL})+(-0.534 \times \mathrm{BoH})+(-0.0334 \times \mathrm{ShL})+(0.241 \times \mathrm{ThL})+(0.728 \times \mathrm{TaL})+(0.244 \times \mathrm{TaW})+ \\ &(0.687 \times \mathrm{ComL})+(-0.784 \times \mathrm{ComH})+(0.144 \times \mathrm{WaL})+(0.049 \times \mathrm{WaH})=(-0.409 \times \mathrm{BoW})-(-95.942) .\end{aligned}$

Where D1, D2 \&D3 =Discriminant functions 1, 2 and 3

BoL $=$ Body Lenght

TaW = Tail Width

$\mathrm{BoH}=$ Body Height

ComH = Comb Height

ShL $=$ Shank Length

ComH = Comb Height

ThL $=$ Thigh Length

ComH $=$ Comb Height

$\mathrm{TaL}=$ Tail Length

WaL = Wattle Length

BoW = Body Width.

\section{Results and Discussion}

Group Statistics. The prediction of group membership is presented in Table 1. Body length, body height, tail and comb length had high standard deviations. The standard deviation of body weight was however low.

Test of Equality of Group Means. There were statistical evidence of significant ( $p>0.05$ ) difference between means of body length, body height, shark length, thigh length, and tail length. Tail width means were highly significant ( $>>0.01)$ between the groups (Table 2). The high standard deviation for some of the independent variables suggested that they were good discriminators as the separation was large. The significant ( $p>0.05$ ) differences between means of body length, body height, shank length, thigh length, tail length and tail width producing high $\mathrm{F}$ values indicated that these variates have high discriminating power and better ability to differentiate the groups. Barrett et al. (1989) also reported similar observation. These variables can be used to characterize and differentiate between isolated populations of local chickens.

Table 1

Group Statistics

\begin{tabular}{clll}
\hline Groups & Variable & \multicolumn{2}{c}{ Mean Standard Deviation } \\
\hline $1 . \quad$ Body length $(\mathrm{cm})$ & 3.7 .97 & 3.82 & 3.54 \\
Body height $(\mathrm{cm})$ & 26.22 & 1.42 \\
Shank length $(\mathrm{cm})$ & 8.41 & 1.55 \\
Thigh length $(\mathrm{cm})$ & 12.08 & 2.17 \\
Tail length $(\mathrm{cm})$ & 14.29 & 2.26 \\
Tail width $(\mathrm{cm})$ & 5.37 & 2.26 \\
Comb length $(\mathrm{cm})$ & 3.76 & 1.35 \\
Comb height $(\mathrm{cm})$ & 1.85 & 0.94 \\
Wattle length $(\mathrm{cm})$ & 2.36 & 1.22 \\
Wattle height $(\mathrm{cm})$ & 1.61 & 0.29 \\
Body weight $(\mathrm{kg})$ & 1.35 & 3.89 \\
2. & 37.56 & 3.66
\end{tabular}


Shank length $(\mathrm{cm})$

Thigh length $(\mathrm{cm})$

Tail length $(\mathrm{cm})$

Tail width $(\mathrm{cm})$

Comb length $(\mathrm{cm})$

Comb height $(\mathrm{cm})$

Wattle length $(\mathrm{cm})$

Wattle height $(\mathrm{cm})$

Body weight $(\mathrm{kg})$

3. Body length $(\mathrm{cm})$

Body height $(\mathrm{cm})$

Shank length $(\mathrm{cm})$

Tail length $(\mathrm{cm})$

Tail width $(\mathrm{cm})$

Comb length $(\mathrm{cm})$

Comb height $(\mathrm{cm})$

Wattle length $(\mathrm{cm})$

Wattle height $(\mathrm{cm})$

Body weight $(\mathrm{kg})$

4.
8.91

12.22

3.78

1.80

2.46

1.61

1.34

38.93

25.63

12.72

13.64

5.27

4.12

2.05

2.48

1.69

1.35

36.96

25.61

8.69

12.00

14.09

4.60

3.49

1.70

2.30

1.45

1.31
1.45

1.66

14.78

4.71

2.17

0.94

2.18

1.22

1.85

1.61

0.26

4.16

2.97

1.11

2.22

0.97

2.21

1.20

0.90

1.17

0.18

3.60

3.31

1.29

1.77

1.92

0.83

2.13

1.22

0.91

1.03

0.25

Table 2 : Test of equality of group means

\begin{tabular}{lllllll}
\hline Variable wilk's & \multicolumn{2}{c}{$\mathrm{f}$} & $\mathrm{df1}$ & $\mathrm{df} 2$ & \multicolumn{2}{c}{ sig. } \\
& lambda & & & & \\
\hline BoL & 0.987 & 3.255 & 3 & 725 & $*$ \\
BoL & 0.995 & 1.253 & 3 & 725 & $*$ \\
ShL & 0.976 & 5.909 & 3 & 725 & $* *$ \\
ThL & 0.992 & 2.058 & 3 & 725 & $*$ \\
TaL & 0.983 & 4.252 & 3 & 725 & $*$ \\
TaW & 0.963 & 9.330 & 3 & 725 & $* * *$ \\
ComL & 0.996 & 0.895 & 3 & 725 & ns \\
ComL & 0.997 & 0.768 & 3 & 725 & ns \\
WaL & 0.998 & 0.555 & 3 & 725 & ns & 1 \\
WaH & 0.997 & 0.752 & 3 & 725 & ns & \\
BoW & 0.998 & 0.524 & 3 & 725 & ns \\
& & & & & & \\
\hline
\end{tabular}

Eigen Values, Canonical Correlation, total and cumulative variance of the discriminant functions. The estimated total shared variance between the optimally weighted discriminant varieties in the groups (Eigen values) are presented in table 3. The percentage of shared variance (72.9) of function 1 was higher than 19.9 and 7.2 of functions 2 and 3 respectively. The canonical correlation of function 1(0.345) was also higher than 0.189 and 0.115 of functions 2 and 3 respectively (Table 3). Total variability in the grouping of 11.90, 3.57 and 1.32 percent were explained by the models of function 1,2 and 3 respectively. The high percentage of shared variance (Eigen value) and total variability in the groupings of discriminant function I indicated that the model in function I was more efficient in explaining the variation existing in the grouping variable than the models of function 2 and 3. The efficiency of the higher canonical correlation which measures the strength of the model to explain the variation existing in the grouping variables was also indicated. Hair et al. (1998) also reported that 
canonical correlation measure the strength explaining the variation in the grouping variables. The higher the value, the higher the strength of the canonical correlation.

Table 3:

Eigen values, canonical correlation, total and cumulative variance of the Discriminant functions

\begin{tabular}{lllllll} 
Functions & $\begin{array}{l}\text { Eigen } \\
\text { Values }\end{array}$ & $\begin{array}{c}\text { Percentage } \\
\text { of variance }\end{array}$ & $\begin{array}{r}\text { Percentage } \\
\text { cumulative }\end{array}$ & $\begin{array}{c}\text { Canonical } \\
\text { Correlation }\end{array}$ \\
\hline 1 & 0.135 & 72.9 & 72.9 & & 0.345 & \\
2 & 0.037 & 19.9 & 92.8 & & 0.189 & \\
3 & 0.013 & 7.2 & & 100.0 & & 0.115 \\
\hline
\end{tabular}

Wilks' Lamba. The significance of the discriminant function as indicated by wilks lambda is present in table 4 . Wilks lambda text indicated that discriminant function I was highly significant $(\mathrm{p}<0.0001)$ through function 3. Discriminant function 2 through 3 was also significant ( $p<0.05$ ). discriminant function 3 was not significant ( $p>$ 0.05 ) (table 4). Three (3) standard canonical discriminant functions were extracted in the study. The significant of the discriminant functions tested with the minimization of wilks' lambda (lambda $=0.838,0.952$ and 0.987 ) and (chi square 126.915, $\mathrm{p}<0.01,35.630 ; \mathrm{p}<0.05$ and 9.533; $<<0.05$ ) for discriminant functions 1,2 and 3 respectively provided the validity for the canonical discriminant analysis. The significance of the discriminant function revealed that the models in discriminant function 1 and 2 were efficient and had strength that differentiated between the groups. The model of discriminant function 3 was less efficient to discriminate between the groups. This was shown by the total variability not explained (97.4\%) of function 3 as compared to 70.2 and 90.6 percents of model 1 and 2 in functions 1 and 2 respectively.

Table 4: Wilks' lambda test.

\begin{tabular}{|c|c|c|c|c|c|c|c|}
\hline $\begin{array}{l}\text { Test of } \\
\text { Function }\end{array}$ & Lambda & $\begin{array}{l}\text { Wilks } \\
\text { Square }\end{array}$ & & Chi & & $\mathrm{df}$ & $\mathrm{Sig}$ \\
\hline 1 to 3 & 0.838 & & 126.915 & 33 & & 0 *** & \\
\hline 2 to 3 & 0.952 & & 35.630 & & 20 & $0.017 *$ & \\
\hline 3 & & 0.987 & & 9.533 & & 9 & $0.390^{\text {ns }}$ \\
\hline
\end{tabular}

Wilks' lambda also provided that the proportion of total variability not explained by the models were 70.22 , 90.63 and 97.42 percent for the models of function, 1, 2 and 3 respectively.

\section{Classification Results}

The classification result is a table in which the rows are the observed categories of the dependent and the columns are the predicted categories. The classification results revealed that 37.72 percent of the birds were classified correctly into the four groups. The birds in group 3 were classified with better accuracy 59.4 percent than bird in group 142.8 percent, followed by 36.4 and 35.2 of birds in group 4 and 2 respectively (table 5).

Table 5 : Classification results.

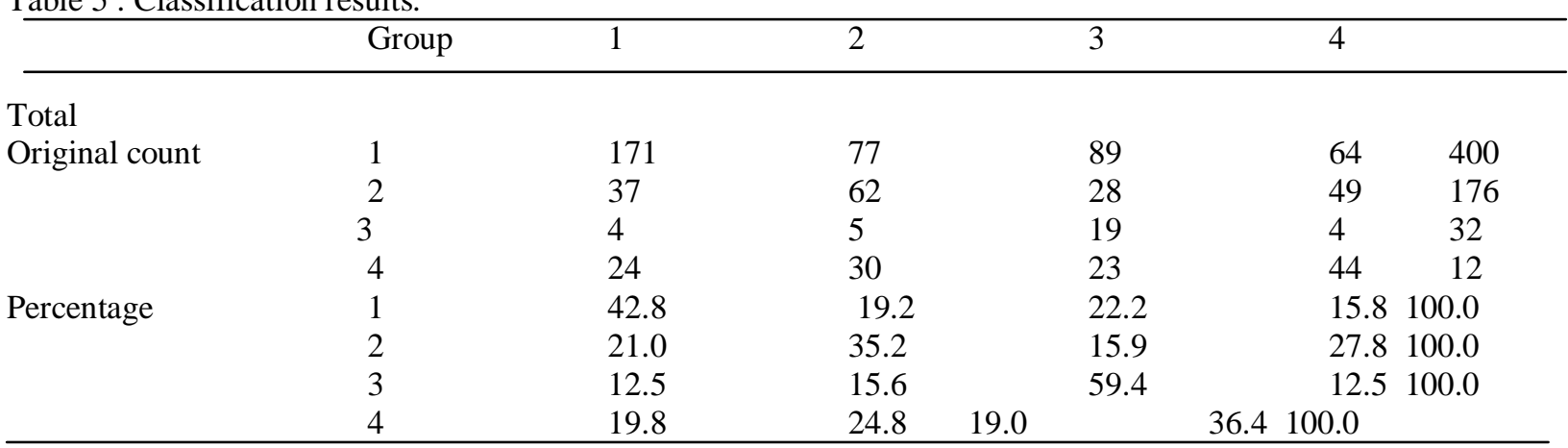

The classification results revealed that 37.72 percent of all the birds were correctly classified into the four groups. The birds in group 3 were classified with better accuracy 59.4 percent than birds in group $1,42.8$ percent; this was followed by 36.4 and 35.2 percent of birds in group 4 and 2 respectively. The prediction was perfect, as all cases lie on the diagonal indicating the percentage of correct classification. Hand, (1981) and 
Yakubu (2011) reported 75 and 96 percent of all cases classified correctly respectively. The lower value of correct classification observed in this study may be because within ecotype, variability may not be too large. It did indicate that morphological measurements can be used to increase consistency of individuals in a population and separation of individuals between populations, this result indicated that there were variations in body dimensions between populations of the Tiv local chicken ecotype. It can also provide basic information for selection and breeding programme. Thus superior birds could be selected and bred for genetic improvement.

\section{Conclusions}

The best discriminant variables in the local chicken were tail length, tail width, shank length, and thigh length and comb height. These measures are consistent and easy to take in the field. The use of biometrics and discriminant analysis may become an important tool for identifying variation in morphological linear measurements between populations. The result might aid in better understanding of the diversity of the Nigerian local chicken ecotypes in the derived guinea savannah zone and breeding for genetic improvement of the rural poultry sector.

\section{Recommendation}

This study should be repeated to provide more information on accurate discriminant variable in the local chicken.

\section{References}

[1]. Adedokun., S.A and Sonaiya, E.B. (2001). Comparison of the performance of Nigeria Indigenous Chickens from three agroecol.,ical zones. Lwest. Res. Rura Dev., 13:1-6

[2]. Alemu., Y. and Tadelle, D. (1997). The States of Poultry Research and Development in Ethiopia. Research Bulletin number 4, Ahemaya university of Agriculture, Page 63

[3]. Barker., J.S.F. (1994). A gloab programme for determining genetic distance among domestic livestock breeds. Proceedings of the $5^{\text {th }}$ world congers on genetic applied to livestock of production 21:501-508

[4]. Danguma, R. (2006). Phenotypic Characterization of some Indigenous Chickens ecotypes of Ethiopia. Livestock Research for Rural Development 18(9).

[5]. Fayeye, T.R., K.L Ayormde, V.Ojo and O.M. Adeaina, (2006). Frequency and influence of some major genes on body weight and body size parameters of Nigerian Local Chickens. Lwest. Res. Rural Dev. Vol. 18 Mo. 12

[6]. Gwaza, D.S. ., Dim, N, I. and Momoh, O.M. (2012) Genetic Study of the Fulani and the Tiv Local Chicken Ecotype in the Derived Guinea Savannah Region of Nigeria. Ph.D these submitted to the Department of Animal Breeding and Physiology, University of Agriculture, Makurdi. Nigeria.

[7]. Hand, D.J. (1981). Discrimination and classification, New York; John Willey \& Sons, Inc

[8]. Ibe, S.N. (1998). Improving productive adaptability of the Nigerian Local Chicken. Proceeding of NSAP Silver Anniversary Conference/WASAP Inaugural Conference, March 21-26, University of Agriculture, Abeokuta PP:464-465.

[9]. Islam, M.A and M. Nashibori. (2009). Indigenous naked Chicken: A valuable genetic resource for Bangladesh. World's poult. Sci., 65:125-138.

[10]. Lashed.,M.A., Howlider., M.A.R Alam., J., Rashid., Kawat., M.H. and Azmal., S.A. (2005). Effect of dwarfism on Reproductive and meat Yield Parameters of crossbred chicken. International Jour. Of poultry Sci., 4(6):372-377

[11]. Lwesya, H., Phoya, R.K D., Safalaoh., A,C.L and Gong T.N.P. (2004). Rearing Chicks in enclosures under Village Conditions, effect of chick growth and reproductive performance of mother hens. Lwestock Res. Rural Dev. 16(89)-Disponible http//www.cipav.org.Irrd/Irrd116/11/we361089.limt

[12]. Momoh, O.M., N.G Ehiobu and C.C Nwosu, (2007) Egg Production of two Nigerian local Chicken Ecotype under Improved management. Proceedings $32^{\text {nd }}$ Annual Conference of NSAP, March 18-22, University of Calabar, Nigeria, PP: 278-281

[13]. Nwosu, C.C. (1990). Review of Indigenous poultry Research. In: Sonaiya, E.B (Editors). Rural Poultry in Africa; Proceeding an international Workshop held on $13^{\text {th }}-16^{\text {th }}$ November, Itleife, Nigeria. Page 6

[14]. Nwosu, C,C., Gowen, F.A., Obiaha., Akpan., I.A. and Onuora., G.I. (1985). A biometrical study of the conformation of the Native Chickens Nigeria Journal of Animal Production; 12:141-146

[15]. Olawunmi, O., Salako, A.E. and Afuwape, A.A. (2008) Morphometic differentiation and assessment of function of the Fulani and Yourba ecotype chickens of Nigeria. Int. J. of morphology 26:975-980

[16]. Olori, V.E. (1992). An evaluation of two Nigerian Indigenous Chickens. M.Sc. Thesis OAU, Ile-Ife.

[17]. Oluyemi, J.A., G.O. Alonge and T. Sungo (1982). Requirement of the Nigerian fowl for protein and amino acids Ife J. Agic.., 4: 105110

[18]. Pedersen,C.V.(2002). Production of Semi-Scavenging and Agricultural University. Copenhagen, Denmark.

[19]. Yakubu, A. (2011): Discrminant Analysis of Sexual dismorphism in Morphological Traits of African Muscovy ducks. 